\title{
Menulis Proposal Tesis
}

\author{
Ismail Suardi Wekke \\ Sekolah Tinggi Agama Islam Negeri (STAIN) Sorong \\ Email: iswekke@gmail.com
}

\begin{abstract}
ABSTRAK
Proposal tesis akan menjadi langkah awal dalam menyelesaikan perkuliah dimana salah satu syarat untuk penyelesaian studi adalah merampungkan seluruh mata kuliah, diantaranya tesis. Jangan sampai tidak memilih topik yang sesuai dengan kemauan dan kemampuan, sehingga mesti mengulangi dari awal lagi. Pengulangan hanya Karena ketidakcermatan di tahapan awal merupakan pemborosan masa.
\end{abstract}

Kata kunci: proposal tesis; menulis akademik; kriteria proposal

\section{Pendahuluan}

Proposal tesis menjadi awal dalam merencanakan tesis yang akan ditulis. Idealnya, topik yang akan dikaji sudah diidentifikasi sejak awal. Sehingga dapat menemukan gap penelitian. Jikalau saja, sebuah tesis hanyalah pengulangan atau bahkan terjebak pada plagiat, akan menjadi boomerang. Menempuh pendidikan master hanya sekali saja, walau ada orang yang mengulanginya. Tetapi itu dengan tesis yang berbeda lagi. Tetap saja, tesis merupakan rangkaian dalam satu masa.

Tesis wajib berbeda dengan skripsi (Wekke, 2017). Jikalau skripsi hanya medeskripsikan sebuah fenomena. Sementara untuk tesis perlu mengemukakan analisis tentang sebuah fenomena. Sehingga peneliti tidak saja memotret sebuah fenomena atau masalah, tetapi menjelaskan fenomena tersebut dalam konteks narasi keilmuan (Cahyono, \& Wekke, 2018). Skripsi merupakan langkah awal dalam mengenali dunia akademik (Saifuddin, Ismail. \& Wekke, 2018). Dengan demikian, jangan sampai menulis tesis yang tidak berbeda sama sekali dengan skripsi. Namun, bisaja saja tema yang dituliskan dari skripsi dilanjutkan pada penulisan tesis, dan seterusnya pada disertasi (Kamler, 2008). Karya ilmiah merupakan bagian dari percakapan akademik, sehingga tema-tema yang ditulis didudukkan dalam konteks percakapan global (Clark, 2006).

\section{Lima Langkah Menulis Proposal Tesis}

Menulis itu tidak bisa dilakukan dengan sekali saja. Perlu langkah-langkah yang teratur sampai pada akhir proses (Glatthorn, \& Joyner, 2005). Perlu juga diperhatikan sejak awal untuk tidak tergesa-gesa dalam menuliskan sebuah proposal sehingga kadang ada bagian-bagian yang terabaikan. Sebelum itu, perhatikan bahwa tema kepemimpinan transformatif dalam pendidikan Islam, ada pakar yang menggolongkannya dalam ranah ilmu sosial (Becker, 2008). Sehingga dapat didekatai dengan penelitian sosial. 
Langkah pertama: Lihat Pedoman Penulisan Proposal di Pasca Sarjana STAIN Sorong. Juga kuasai aplikasi manajemen referensi seperti Mendeley sehingga memudahkan penulisan. Ingat, model referensi yang digunakan Chicago Style dengan penggunaan footnote. Cek kembali gaya yang digunakan sehingga ada keakuratan referensi dan juga kecermatan dalam menuliskan daftar pustaka (Turabian, 2013). Dengan menggunakan aplikasi teknologi informasi, bisa lebih akurat dan cermat (Nur, Sabara, \& Wekke, 2018).

Langkah kedua: Temukan Masalah Penelitian. Cek fakta lapangan, kemudian telusuri kepustakaan. Masalah akan muncul dimana ada kesenjangan antara fakta dengan teori atau publikasi yang sudah ada. Masalah juga dapat dikenali dengan mengidentifikasi topik penelitian apa saja yang sudah terpublikasi (Wekke, 2018).

Masalah penelitian akan memberi pilihan pada pendekatan penelitian. Dengan memilih "cara menjawab" masalah, akan memudahkan untuk pengumpulan data. Dengan mengemukakan angka bukan berarti itu secara otomatis akan menjadi kuantitatif. Sebaliknyapun tidak dengan kata-kata saja akan menjadi kualitatif. Ada pula sebuah masalah yang dapat dijawab hanya dengan angka saja (Nenty, 2009).

Baca lagi tulisan Creswell, \& Poth (2017), Creswell (2010), Creswell, Hanson, Clark Plano, \& Morales, (2007) terkait dengan pendekatan penelitian. Jika memilih pendekatan kualitatif, baca kembali Muhadjir (1996). Sementara jika memilih pendekatan kuantitatif, maka temukan orang yang dapat membantu menganalisis data menggunakan aplikasi seperti SPSS.

Langkah ketiga: Kemukakan Penelitian Terdahulu. Cek di pangkalan data seperti Google Scholar, DOAJ, dan juga ERIC (terutama untuk penelitian pendidikan) untuk mendapatkan informasi global. Tesis, idealnya berwawasan global.

Begitu pula kunjungi perpustakaan STAIN Sorong, Universitas Muhammadiyah Sorong, dan Universitas Pendidikan Muhammadiyah Sorong, untuk mengecek topik yang sama, atau bahkan skripsi mahasiswa yang sudah menuliskan locus penelitian yang sama. Penelitian dalam jurusan pendidikan di ketiga perguruan tinggi itu akan memberikan kesempatan untuk tidak melakukan pengulangan dalam penelitian. Walaupun tempat penelitian yang sama, bisajadi memiliki perspektif dan juga analisis yang berbeda.

Sebuah tesis berada dalam konteks keilmuan secara global. Maka, jangan sampai tidak membaca penelitian-penelitian yang sudah dilakukan di seluruh dunia terkait dengan topik yang sementara ditulis.

Langkah keempat: Tuliskan Kerangka Usulan. Bisajadi berubah, namun sudah ada gambaran tulisan proposal yang akan dikonsultasikan dengan pembimbing. Ini dapat diperbaiki selanjutnya setelah ujian berdasarkan saran dan pertanyaan dosen penguji semasa ujian proposal.

Dengan mulai menuliskan draft awal, ada materi yang dapat didiskusikan dengan pembimbing. Kalau hanya sekadar diskusi lisan, maka dikhawatirkan hanya akan berlalu begitu saja. Maka 
sebuah draft dalam tahap apapun, akan lebih baik kalau hanya masih perencanaan tanpa sebuah draft sama sekali.

Langkah kelima: konsultasi kembali dengan direktur pasca kesesuaian antara proposal dengan panduan penulisan. Begitu pula dengan pembimbing, jangan lupa untuk berdiskusi secara terjadwal sehingga dapat menuliskan proposal sesuai dengan kriteria standar minimal sebuah tesis.

Setelah semuanya, paling penting adalah tahapan terakhir yaitu mendaftar untuk ujian proposal. Sekalipun proposal sudah bagus, tetapi kalau tidak mendaftar, maka tidak akan pernah melangkah ke tahapan ujian proposal.

Perhatikan pula soal waktu. Setelah ujian proposal, perlu tiga bulan untuk ujian hasil. Setelah ujian hasil perlu sebulan untuk ujian tertutup. Pola 1-3-1 dijadikan sebagai panduan. Jika tidak, akibatnya akan menyeberang ke semester berikutnya dengan konsekwensi membayar lagi SPP.

Satu hal lagi, menulis tesis dengan kemampuan terbaik. Jangan pernah selalu menggunakan argumentasi bahwa perguruan tinggi Papua terkebelakang (Wekke, Kahar, \& Amri, 2018). Justru dengan berada di Tanah Papua, ada kesempatan untuk melakukan aktivitas yang memungkinkan untuk penerokaan ilmu pengetahuan dimana ada saja topic yang belum tereksplorasi dalam bentuk publikasi.

\section{Penutup}

Proposal merupakan usulan, ini dapat ditambah atau dikurangi pada kesempatan berikutnya. Sehingga ide yang sudah dipilih diteruskan dengan proses penulisan lebih lanjut. Semakin dipendam, akan semakin menguap. Sebaliknya, perlu didiskusikan, dituliskan, dan ditelusuri konteksnya dalam diskursus keilmuan secara global.

Selamat bekerja.

\section{Daftar Pustaka}

Becker, H. S. (2008). Writing for social scientists: How to start and finish your thesis, book, or article. University of Chicago Press.

Cahyono, D., \& Wekke, I. S. (2018). Teknik Penyusunan dan Penulisan Tesis. Yogyakarta: Deepublish.

Clark, I. (2006). Writing the successful thesis and dissertation: Entering the conversation. Prentice Hall Press.

Creswell, J. W. (2010). Research design pendekatan kualitatif, kuantitatif, dan mixed. Yogyakarta: Pustaka Pelajar.

Creswell, J. W., \& Poth, C. N. (2017). Qualitative inquiry and research design: Choosing among five approaches. Sage publications.

Creswell, J. W., Hanson, W. E., Clark Plano, V. L., \& Morales, A. (2007). Qualitative research designs: Selection and implementation. The counseling psychologist, 35(2), 236-264.

Glatthorn, A. A., \& Joyner, R. L. (2005). Writing the winning thesis or dissertation: A step-bystep guide. Corwin Press. 
Kamler, B. (2008). Rethinking doctoral publication practices: Writing from and beyond the thesis. Studies in Higher Education, 33(3), 283-294.

Muhadjir, N. (1996). Metodologi penelitian kualitatif: pendekatan positivistik, rasionalistik, phenomenologik, dan realisme metaphisik telaah studi teks dan penelitian agama. Yogyakarta: Rake Sarasin.

Nenty, H. J. (2009). Writing a quantitative research thesis. International Journal of Educational Sciences, 1(1), 19-32.

Nur, T., Sabara, H. Z., \& Wekke, I. S. (2018). Teknik Menulis Karya Ilmiah: Dengan 8 Senjata Aplikasi Pendukung Produktivitas Riset. Yogyakarta: Deepublish.

Saifuddin, S., Ismail. M. S., \& Wekke, I. S. (2018). Strategi dan Teknik Penulisan Skripsi. Yogyakarta: Deepublish.

Turabian, K. L. (2013). A manual for writers of research papers, theses, and dissertations: Chicago style for students and researchers. University of Chicago Press.

Wekke, I. S. (2017). Penyempurnaan Penulisan Skripsi. https://doi.org/10.31227/osf.io/qjxr5.

Wekke, I. S. (2018). Memulai Penelitian Dengan Menganalisis Topik Keilmuan. https://doi.org/10.31227/osf.io/yfrqz.

Wekke, I. S., Kahar, M. S., \& Amri, I. (2018). Perguruan Tinggi Tanah Papua dan Strategi Pengembangan Pendidikan Tinggi. https://doi.org/10.31227/osf.io/m3kvb. 